\title{
GLUCOSE UPTAKE BY RABBIT GESTATIONAL MYOMETRIUM
}

\author{
D. E. SMITH \\ Department of Zoology North Carolina State University, \\ Raleigh, North Carolina 27607, U.S.A. \\ (Received 10th March 1972, accepted 28th March 1972)
}

\begin{abstract}
Summary. Determinations of glucose uptake were made using myometrial tissue from non-pregnant and pregnant rabbits. Sugar uptake was measured during incubation in vitro under aerobic conditions. In non-pregnant animals, uptake was over two times greater in oestrous than in anoestrous animals, suggesting that glucose uptake is related to oestrogen stimulation. During pregnancy, myometrial glucose uptake is related to proximity of the placenta. Tissue in contact with the placenta shows lower glucose uptake than tissue not in contact with the placenta until about the 26th day of gestation. On Day 30, this relationship is reversed and sugar uptake by tissue in contact with the placenta increases to levels similar to those found in myometrium from oestrous rabbits.
\end{abstract}

Normal endogenous changes in steroid levels in the hamster cause an increase in uterine glucose metabolism at oestrus (Warren, Cheatum, Greenwald \& Barker, 1967). Saldarini \& Yochim (1968) have also reported that glucose utilization by rat endometrium is correlated with ovarian steroid secretion during oestrous cycles and early pseudopregnancy. Based on such observations, it seems likely that steroid secretions from the ovary and placenta cause alterations in myometrial glucose metabolism during gestation. Experiments described here were conducted to determine glucose uptake by rabbit myometrium during the course of pregnancy. Particular attention was given to the local influence of the placenta.

Eighteen, individually-caged, female, New Zealand white rabbits (2 to $3 \mathrm{~kg}$ body weight) were used in this study. Pregnancy was initiated by mating sexually receptive (oestrus) females with a fertile buck, and days of gestation were counted by designating the day after copulation as Day l. At the desired stage of pregnancy, animals were killed and their uteri were excised and placed immediately in ice-cold Krebs-Ringer-bicarbonate medium. Segments of myometrium were gently scraped to remove endometrium and pieces weighing approximately $200 \mathrm{mg}$ were prepared for incubation in 25-ml Erlenmeyer flasks. Tissues studied included myometrium located over embryos with no placental contact and tissue in contact with the placenta. The latter type of tissue is not available until 10 to 12 days of gestation. Pieces of myometrium were incubated in $3 \mathrm{ml} \mathrm{Krebs-Ringer-bicarbonate} \mathrm{medium} \mathrm{(} \mathrm{pH} \mathrm{7.4)} \mathrm{contain-}$ ing $1 \mathrm{mg} / \mathrm{ml}$ glucose and $4 \mathrm{mU} / \mathrm{ml}$ zinc insulin (Lilly) for $2 \mathrm{hr}$ at $37^{\circ} \mathrm{C}$ in an 
atmosphere of $95 \% \mathrm{O}_{2}: 5 \% \mathrm{CO}_{2}$ with constant shaking. Following incubation, the tissue was removed, blotted and weighed. Glucose uptake was determined by measuring the glucose concentration of the medium before and after incubation. Medium samples were assayed on a Technicon AutoAnalyzer which measured absorbance at $420 \mathrm{~m} \mu$ of $\mathrm{KFe}(\mathrm{CN})_{6}$ reduced by glucose.

During incubation in vitro, all tissues were supplied with equal amounts of insulin to ensure that variations in glucose uptake were not due to this hormone. Myometrial pieces incubated with and without insulin showed that insulin caused a 3 to $6 \%$ increase in glucose uptake. Tissue which was previously quick frozen $\left(-10^{\circ} \mathrm{C}\right)$ showed no glucose uptake by these methods.

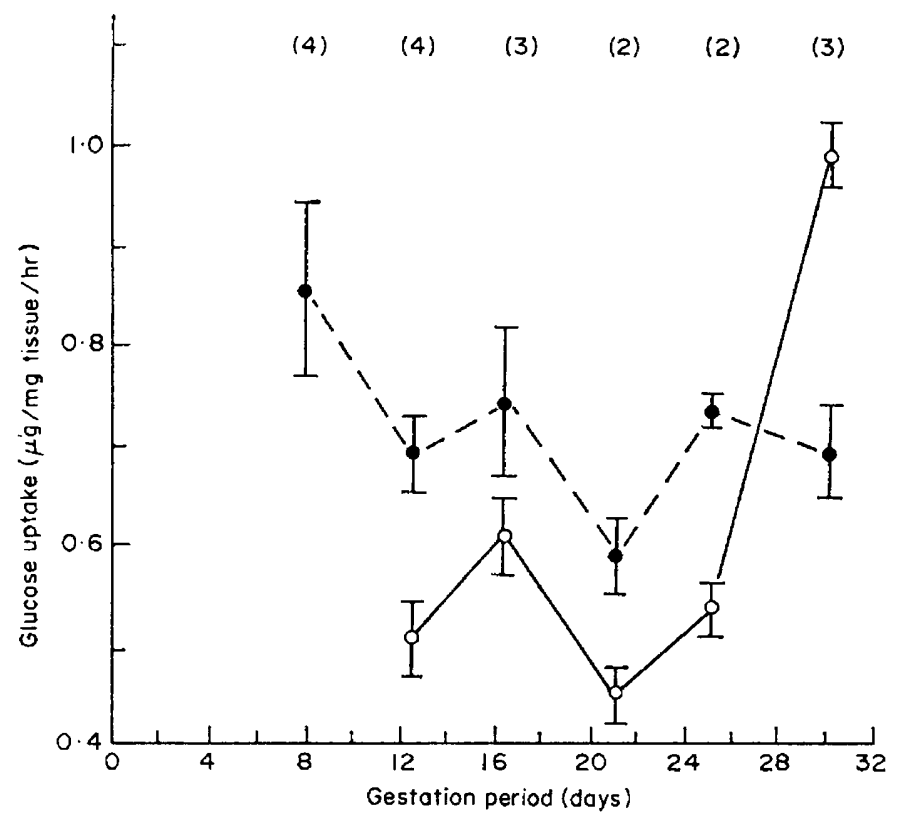

TEXT-Fig. 1. Myometrial glucose uptake during pregnancy in the rabbit. Values are means \pm S.E. based on the number of animals indicated in parentheses. Tissue types: (•) myometrium not in contact with placenta, (O) myometrium in contact with placenta.

Individual female rabbits displayed marked differences in sexual receptivity and myometrial glucose uptake was found to be related to this receptivity. In two does killed immediately after copulation, glucose uptake was $1 \cdot 16 \pm 0.05$ and $1.01 \pm 0.07 \mu \mathrm{g} / \mathrm{mg}$ tissue $/ \mathrm{hr}$ (values are means \pm S.E. based on four separate tissue determinations in each case). In six animals not exhibiting lordosis, uptake averaged $0.48 \pm 0.06 \mu \mathrm{g} / \mathrm{mg}$ tissue $/ \mathrm{hr}$ where values from individual animals ranged from $0.35 \pm 0.02$ to $0.63 \pm 0.04 \mu \mathrm{g} / \mathrm{mg}$ tissue $/ \mathrm{hr}$. Since samples of highly vascularized tissue from receptive (oestrus) animals showed an 8 to $10 \%$ higher water content, uptake values for these tissues have probably been underestimated.

Glucose uptake by the myometrium of pregnant rabbits was determined at about 4-day intervals during gestation (Text-fig. 1). Tissue in contact with the 
placenta displayed lower uptake values than tissue not in contact with the placenta except at the end of gestation. A $t$ test analysis showed that uptake values in these two tissue types are significantly different $(P<0.05)$ except at 16 days of pregnancy.

The observation that high glucose uptake coincides with sexual receptivity suggests that uptake is related to a cyclic secretion of oestrogen in rabbits (Hamilton, 1951; Myers \& Poole, 1962). Similar relationships have been observed in rat endometrium (Saldarini \& Yochim, 1968) and hamster uterus (Warren et al., 1967). Although little is known about progesterone effects on uterine sugar metabolism, utilization of exogenous glucose by rat endometrium is low and stable during pseudopregnancy (Saldarini \& Yochim, 1968).

Mikhail, Noall \& Allen (1961) and Hilliard, Spies \& Sawyer (1968) have shown that rabbit ovarian progesterone secretion is highest at mid-pregnancy and gradually decreases until parturition. Recently, Eaton \& Hilliard (1971) found that ovarian progesterone and oestradiol-17 $\beta$ secretion is higher at 18 days than at Days 21 or 26 of pregnancy. Present evidence therefore suggests a diminishing ovarian steroid secretion during late pregnancy in rabbits.

Acute doses of oestradiol-17 $\beta$ lead to prompt increases in uterine glucose metabolism in immature or ovariectomized animals. This effect appears to be related to oestrogen stimulation of sugar transport and/or phosphorylation (Roskoski \& Steiner, 1967; Smith \& Gorski, 1968; Smith \& Stultz, 1971). Enhanced glucose uptake by preparturient myometrium in contact with the placenta could be due to localized secretion of oestradiol- $17 \beta$ by the placenta. An analysis of placental steroid secretion and tissue steroid content will be required to account for changes in myometrial metabolism during pregnancy.

This investigation was supported in part by research grant GB8386 from the National Science Foundation.

\section{REFERENCES}

Eaton, L. W. \& Hilliard, J. (1971) Oestradiol-17 $\beta$, progesterone and $20 \alpha$-hydroxypregn-4-en-3-one in rabbit ovarian venous plasma. I. Steroid secretion from paired ovaries with and without corpora lutea; effect of LH. Endocrinology, 89, 105.

Hamilton, C. E. (1951) Evidences of cyclic reproductive phenomena in the rabbit. Anat. Rec. 110, 557.

Hilliard, J., SpIES, H. G. \& SAwYer, C. H. (1968) Cholesterol storage and progestin secretion during pregnancy and pseudopregnancy in the rabbit. Endocrinology, 82, 157.

Mikhail, G., Noall, M. W. \& Allen, W. M. (1961) Progesterone levels in the rabbit ovarian vein blood throughout pregnancy. Endocrinology, 69, 504.

Myers, K. \& Poole, W. E. (1962) Oestrous cycles in the rabbit Oryctolagus cuniculus (L.). Nature, Lond. $195,358$.

Roskoskr, R., JR \& Steiner, D. F. (1967) The effect of estrogen on sugar transport in the rat uterus. Biochim. biophys. Acta, 135, 717.

Smith, D. E. \& GoRsKI, J. (1968) Estrogen control of uterine glucose metabolism: an analysis based on the transport and phosphorylation of 2-deoxyglucose. F. biol. Chem. 243, 4169.

Sмтth, D. E. \& Stultz, M. S. (1971) Properties of estrogen-sensitive uterine sugar metabolism: specificity of inhibitory sugars. Endocrinology, 88, 218.

SAldarini, R. J. \& Yochim, J. M. (1968) Glucose utilization by endometrium of the uterus of the rat during early pseudopregnancy and its regulation by estrogen and progesterone. Endocrinology, $82,511$.

Warren, J. G., Cheatum, S. G., Greenwald, G. S. \& Barker, K. L. (1967) Cyclic variation of uterine metabolic activity in the golden hamster. Endocrinology, 80, 714. 